\title{
Strength Attainment of Geopolymer Concrete with GGBS at Ambient Curing
}

\author{
"Ganesan Nagalingam, Ramesh Babu Chokkalingam, Meyyappan PL
}

\begin{abstract}
Geopolymer concrete plays a major role in concrete industry by replacing cement and using the industrial wastes. In this study, the cement is completely replaced by GGBS and strength properties are analyzed. An M30 mix design is prepared and the specimens are cast and tested. For this, sodium hydroxide and sodium silicate are used as activator and its ratio is fixed as 1:2.5. Sodium hydroxide of 12 molarity, $550 \mathrm{~kg} / \mathrm{m}^{3}$ of $G G B S$ is used in the study. Admixture La Hypercrete S25 (HTS code 38244090 ) is added in the mix by $1 \%$ of weight of GGBS to obtain the required workability. For compression study, cubes in $100 \mathrm{~mm}$ size are cast. Cylinders with $100 \mathrm{~mm}$ dia and $200 \mathrm{~mm}$ height are tested for splitting tensile strength and beam specimens of $500 \mathrm{~mm}$ long and 100mm cross sections were cast for determining the flexure behaviour. The beams are subjected to ambient curing and tested at 3, 7, 14, 28 and 56 days. The test result shows that there is a gradual increment in all the strengths from 3 to 56 days and it proves that geopolymer concrete with GGBS cured at ambient temperature performs well in the strength properties.
\end{abstract}

Keywords: activator, admixture, ambient curing, Geopolymer concrete, GGBS

\section{INTRODUCTION}

To save nature, many industrial wastes are converted as concrete making aggregates. We know that production and usage of cement increases every day. Nearly one tonne of carbon di oxide is emitted for every one tonne cement production. This not only spoils the environment but also depletes natural resources. Many attempts have been tried to use alternate material in the place of conventional aggregates. Ground Granulated Blast Furnace Slag (GGBS) is one among them which completely eliminates the usage of cement [1] Many researchers have tried fly ash and GGBS for cement. In this study, cement is completely replaced by GGBS and a geopolymer concrete mix is prepared and specimens are cast and tested for strength properties. Many

Revised Manuscript Received on December 30, 2019.

* Correspondence Author

*Ganesan Nagalingam, Department of Civil Engineering, Kalasalingam Tamilnadu . Email: civilganesan139@gmail.com

Ramesh Babu Chockkalingam, Department of Civil Engineering, Virudhunagar District, Tamilnadu . Email: babussr@gmail.com

Meyyappan PL, Department of Civil Engineering, Kalasalingam Academy of Research and Education ,Krishnankoil, Virudhunagar District, Tamilnadu . Email: meyyappan@klu.ac.in Academy of Research and Education, Krishnankoil, Virudhunagar District, Kalasalingam Academy of Research and Education Krishnankoil,

studies reveal that geopolymer concrete exhibits good resistance to chemicals, reduced shrinkage, creep and remarkable compressive

strength [2] Polycondensation of silica and alumina in geopolymer concrete is responsible for strength attainment [3] Many researchers found good increment in compressive strength when geopolymer concrete is prepared with fly ash[4]. Studies also prove that ductility property and strength increases when geopolymer concrete is tested with confinement reinforcement. [5] Solid activators are also tried in geopolymer concrete for better field applications and acceptances [6]

\section{MATERIALS}

\section{A. Fine aggregate}

IS 383 - 1970 confirmed river sand was used in this study. [7] One kg of fine aggregate was taken for conducting the test. From the sieve analysis test on particle size distribution, it was found that the fine aggregate belongs to Zone- 2 .

\begin{tabular}{|l|c|c|c|c|}
\hline Sieve & $\begin{array}{c}\text { Weight } \\
\text { reserved } \\
\text { (gms) }\end{array}$ & $\begin{array}{c}\text { Cumulative } \\
\text { weight } \\
\text { reserved(gms) }\end{array}$ & $\begin{array}{c}\text { Cumulative } \\
\text { \% weight } \\
\text { reserved }\end{array}$ & $\begin{array}{c}\% \\
\text { Finer }\end{array}$ \\
\hline $4.75 \mathrm{~mm}$ & 48 & 48 & 4.8 & 95.2 \\
\hline $2.36 \mathrm{~mm}$ & 77 & 125 & 12.5 & 87.5 \\
\hline $1.18 \mathrm{~mm}$ & 396 & 521 & 52.1 & 47.9 \\
\hline $600 \mu \mathrm{m}$ & 285 & 806 & 80.6 & 19.4 \\
\hline $300 \mu \mathrm{m}$ & 152 & 958 & 95.8 & 4.2 \\
\hline $150 \mu \mathrm{m}$ & 36 & 994 & 99.4 & 0.6 \\
\hline Pan & 6 & 1000 & 100 & 0 \\
\hline
\end{tabular}

Table- I: Particular size distribution (Fine Aggregate)

B. Coarse aggregate

Coarse aggregate confirms to IS: 383 - 1970 was used in the test. $5 \mathrm{~kg}$ of aggregate was taken for the test. The locally available coarse material was used in the experimental work. Sieve analysis was conducted for particle sharing. The values obtained in the test were tabulated in the table shown below. The fineness modulus of the aggregate was found to be 7.07.

\section{GGBS}

GGBS was collected from slag industries (Salem steel Plant, Tamilnadu) and it was a white powder. It was obtained from Bangalore. XRF analysis was done in Central Electro Chemical Research Institute, Karaikudi. From the XRD analysis it was found that the calcium content is high in the GGBS. Also the XRF analysis shows that the GGBS is highly resistant to chemicals such as sulphates etc. The percentage of calcium is the reason for the strength attainment of the GGBS based geopolymer concrete. 


\section{Strength Attainment of Geopolymer Concrete with GGBS at Ambient Curing}

Table- II: Particular size distribution (Coarse Aggregate)

\begin{tabular}{|c|c|c|c|c|}
\hline Sieve & $\begin{array}{c}\text { Weight } \\
\text { reserved } \\
(\text { gms })\end{array}$ & $\begin{array}{c}\text { Cumulative } \\
\text { weight } \\
\text { reserved(gms) }\end{array}$ & $\begin{array}{c}\text { Cumulative } \\
\text { \% weight } \\
\text { reserved }\end{array}$ & $\begin{array}{c}\% \\
\text { Finer }\end{array}$ \\
\hline $80 \mathrm{~mm}$ & - & - & 100 & 0 \\
\hline $40 \mathrm{~mm}$ & - & - & 100 & 0 \\
\hline $20 \mathrm{~mm}$ & 1.85 & 37.0 & 63.0 & 37 \\
\hline $10 \mathrm{~mm}$ & 1.63 & 32.6 & 67.4 & 69.6 \\
\hline $4.75 \mathrm{~mm}$ & 1.52 & 30.4 & 69.6 & 100 \\
\hline $2.36 \mathrm{~mm}$ & 0 & 0 & 100 & 100 \\
\hline $1.18 \mathrm{~mm}$ & 0 & 0 & 100 & 100 \\
\hline $600 \mu \mathrm{m}$ & 0 & 0 & 100 & 100 \\
\hline $300 \mu \mathrm{m}$ & 0 & 0 & 100 & 100 \\
\hline $150 \mu \mathrm{m}$ & 0 & 0 & 100 & 100 \\
\hline
\end{tabular}

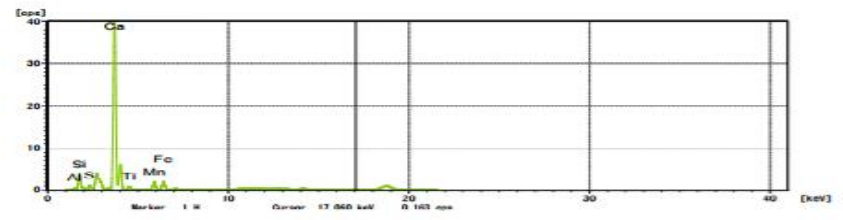

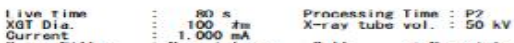

Nonoxietenoe coll

Quant. Corr.

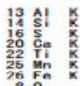
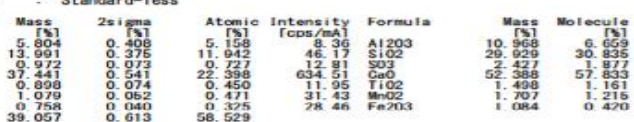

Fig. 1. XRF Analysis of GGBS

\section{Activator solution}

Prior to 24 hours of casting of specimens, activator solution was prepared. 12 molarity sodium hydroxide solution and sodium silicate was mixed at the ratio of 1:1.25.

\section{E. Admixture}

To have excellent workability, La- Hypercrete S25 (HTS code 38244090 ) was added at $1 \%$ of the weight of GGBS.[8]

\section{F. Mix proportion for the experimental work}

The proportions of materials used in this experimental work is tabulated below.[9]

Table- III: Materials for the experimental work

\begin{tabular}{|c|c|c|c|c|c|c|}
\hline Materials & $\begin{array}{c}\text { GG } \\
\text { BS }\end{array}$ & FA & CA & $\begin{array}{c}\text { Na } \\
\text { OH }\end{array}$ & $\begin{array}{c}\mathbf{N a}_{2} \\
\mathbf{S i O}_{3}\end{array}$ & $\begin{array}{c}\text { Ad-mixt } \\
\text { ure }\end{array}$ \\
\hline $\begin{array}{c}\text { Quantity } \\
\left(\mathrm{kg} / \mathrm{m}^{3}\right)\end{array}$ & 550 & 689.10 & 1113.2 & 55 & 137.5 & 5.5 \\
\hline
\end{tabular}

\section{EXPERIMENTAL WORK}

\section{A. Compression test}

$100 \mathrm{~mm}$ size cube specimens were cast to study the compression behavior using the mix mentioned above. The cubes were cast as per the codal guide lines. All the cubes were subjected to ambient curing (ie) cured at room temperature. The cubes after 3, 7, 14, 28 and 56 days were subjected to compression test and the loads were noted. The values obtained were given below.

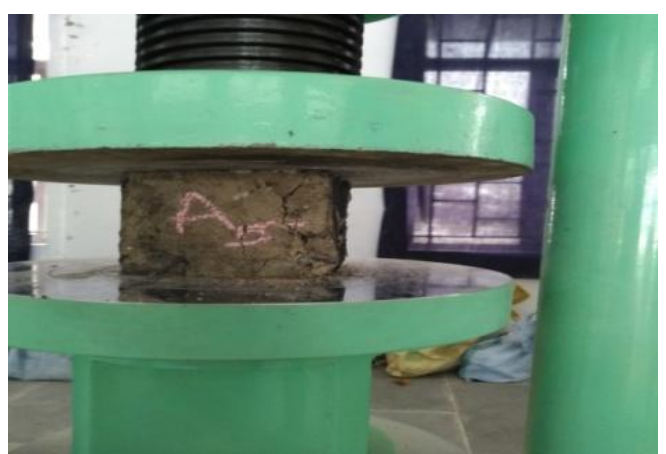

Fig. 2. Compression test set up

Table- IV: Compressive strength values at various curing days in $\mathrm{N} / \mathrm{mm}^{2}$

\begin{tabular}{|c|c|c|c|c|c|}
\hline Specimen & $\mathbf{3}$ & $\mathbf{7}$ & $\mathbf{1 4}$ & $\mathbf{2 8}$ & $\mathbf{5 6}$ \\
\hline 1 & 30.2 & 30.4 & 39.8 & 46 & 53 \\
\hline 2 & 32.2 & 38.4 & 39.2 & 60.5 & 68 \\
\hline 3 & 37.4 & 37.6 & 38.6 & 51 & 61 \\
\hline $\begin{array}{c}\text { Average } \\
\left(\mathrm{N} / \mathrm{mm}^{2}\right)\end{array}$ & 33.26 & 35.46 & 39.20 & 52.50 & 60.67 \\
\hline
\end{tabular}

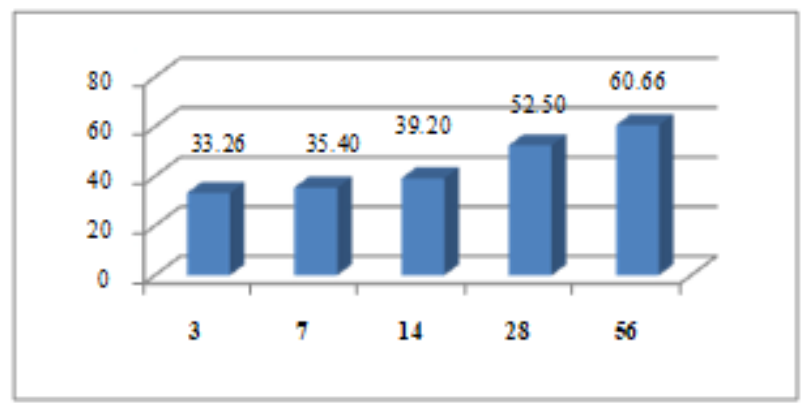

Fig. 3. Compressive strength values at various curing days in $\mathrm{N} / \mathrm{mm}^{2}$

\section{B. Split tensile test}

For split tensile test, cylinders were cast. These cylinder diameters were $150 \mathrm{~mm}$ and height $300 \mathrm{~mm}$ and tested at 3,7 , 14, 28 and 56 days. Specimens after subjected to ambient curing were tested for split tension.

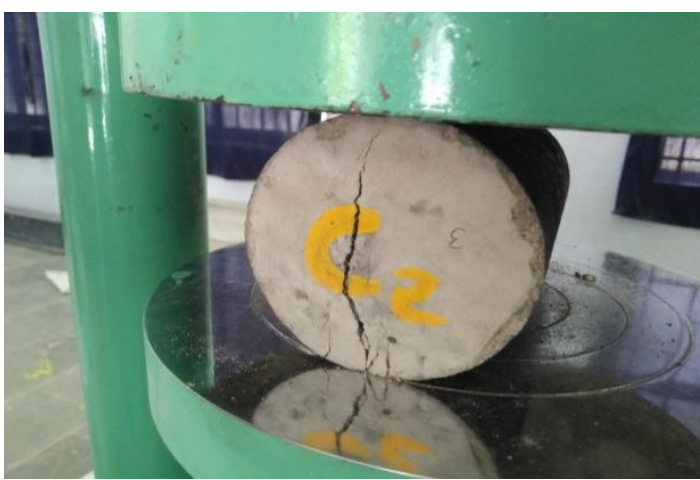

Fig. 4. Split tensile test set up 
Table- V: Split tensile values at various curing days in $\mathrm{N} / \mathrm{mm}^{2}$

\begin{tabular}{|c|c|c|c|c|c|}
\hline Specimen & $\mathbf{3}$ & $\mathbf{7}$ & $\mathbf{1 4}$ & $\mathbf{2 8}$ & $\mathbf{5 6}$ \\
\hline 1 & 1.46 & 1.46 & 1.5 & 1.97 & 2.38 \\
\hline 2 & 1.27 & 1.21 & 1.7 & 1.84 & 3.02 \\
\hline 3 & 1.08 & 1.27 & 1.97 & 2.6 & 2.38 \\
\hline $\begin{array}{c}\text { Average } \\
\left(\mathrm{N} / \mathrm{mm}^{2}\right)\end{array}$ & $\mathbf{1 . 2 7}$ & $\mathbf{1 . 3 1 3}$ & $\mathbf{1 . 7 2}$ & $\mathbf{2 . 1 3}$ & $\mathbf{2 . 5 9}$ \\
\hline
\end{tabular}

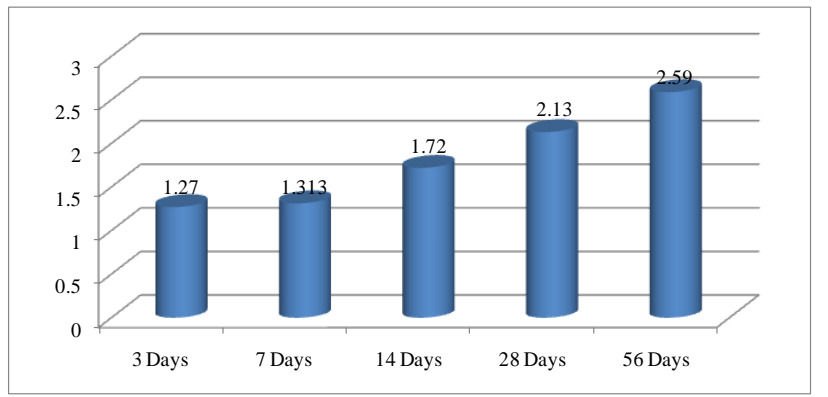

Fig. 5. Split tensile values at various curing days in $\mathbf{N} / \mathbf{m m}^{2}$

\section{Flexure test}

Beam specimens of $500 \mathrm{~mm}$ long and $100 \mathrm{~mm}$ cross section were cast for determining the flexural strength behavior. The specimens were subjected to flexural testing after 3, 7, 14, 28 and 56 days of ambient curing.

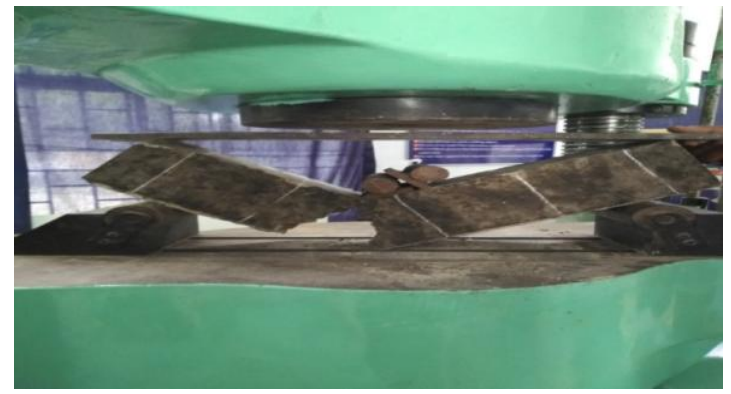

Fig. 6. Flexure test set up

Table- VI: Flexural strength values at various curing days in $\mathrm{N} / \mathrm{mm}^{2}$

\begin{tabular}{|c|c|c|c|c|c|}
\hline Specimen & $\mathbf{3}$ & $\mathbf{7}$ & $\mathbf{1 4}$ & $\mathbf{2 8}$ & $\mathbf{5 6}$ \\
\hline 1 & 9.525 & 12.025 & 14.00 & 16.075 & 16.15 \\
\hline 2 & 10.65 & 11.675 & 11.8 & 15.05 & 14.375 \\
\hline 3 & 10.125 & 10.975 & 11.6 & 14.175 & 17.05 \\
\hline $\begin{array}{c}\text { Average } \\
\left(\mathrm{N} / \mathrm{mm}^{2}\right)\end{array}$ & $\mathbf{1 0 . 1 1}$ & $\mathbf{1 1 . 5 5}$ & $\mathbf{1 2 . 4 6}$ & $\mathbf{1 5 . 1 1}$ & $\mathbf{1 5 . 8 5}$ \\
\hline
\end{tabular}

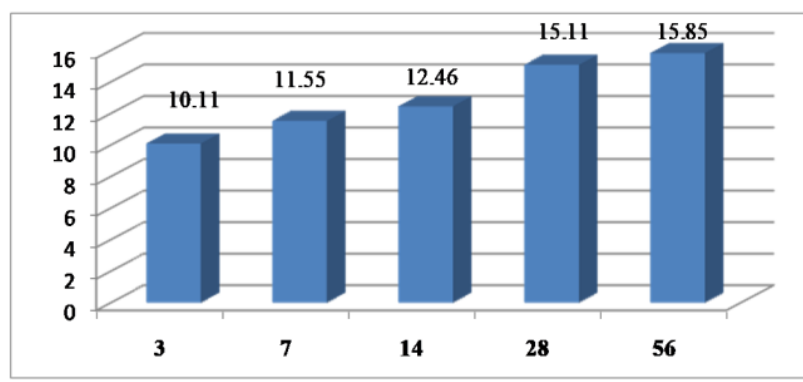

Fig.7. Flexural strength values at various curing days in $\mathbf{N} / \mathbf{m m}^{2}$

\section{RESULTS WITH DISCUSSION}

\section{A. Compression test}

From the compressive test result tables, it was found that the average value of 3 days compressive strength was 33.26 $\mathrm{N} / \mathrm{mm}^{2}$ and the values gradually increased for other days. These values at $7,14,28$ and 56 days were $35.4 \mathrm{~N} / \mathrm{mm}^{2}$, $39.2 \mathrm{~N} / \mathrm{mm}^{2}, 52.5 \mathrm{~N} / \mathrm{mm}^{2}$ and $60.67 \mathrm{~N} / \mathrm{mm}^{2}$ respectively. It showed that the compressive strength value increased with time.

\section{B. Splitting tensile test}

The average splitting tensile test results for 3, 7, 14, 28 and 56 days were $1.27 \mathrm{~N} / \mathrm{mm}^{2}, 1.313 \mathrm{~N} / \mathrm{mm}^{2}, 1.72 \mathrm{~N} / \mathrm{mm}^{2}$, $2.13 \mathrm{~N} / \mathrm{mm}^{2}$ and $2.59 \mathrm{~N} / \mathrm{mm}^{2}$ respectively. It also showed that there was an increment with increase in the age of concrete.

\section{Flexure test}

The average flexural strength results for 3, 7, 14, 28 and 56 days also showed remarkable increase and found to be 10.1 $\mathrm{N} / \mathrm{mm}^{2}, 11.55 \mathrm{~N} / \mathrm{mm}^{2}, 12.46 \mathrm{~N} / \mathrm{mm}^{2}, 15.1 \mathrm{~N} / \mathrm{mm}^{2}$ and 15.85 $\mathrm{N} / \mathrm{mm}^{2}$ respectively. From this test, it was proved that geopolymer concrete performed well for flexure test also with age.

\section{CONCLUSION}

From this experimental work, it was concluded that geopolymer concrete with GGBS and complete elimination of cement cured at ambient temperature performed well for all the three strength related tests. It is observed that, the activator ratio 1:1.25 polymerizes the materials (GGBS and aggregates) in to the molecular chains and its networks is enhanced the binding property. This ensures the good Geopolymerization process for that concerned the activator ratio due to the formation of effective alumina-silicate gel which assures the binding property of the concrete. It also showed gradual increment with age of concrete. So, geopolymer concrete proved that it was an alternative for ordinary conventional concrete with cement.

\section{RECOMMENDATIONS}

(i) The performance of geopolymer concrete can be tried for structural applications.

(ii) By varying the activator ratio, the changes on the strength behavior can be analyzed.

(iii) Geopolymer concrete can be tested for durability properties.

\section{REFERENCES}

1. M.C.G. Juenger, F. Winnfield, J.L. Provis and J.H. Ideker,"Advances in alternative cementitious binders," Cement and Concrete Research, 2010, pp.1232-1243, vol. 41

2. Hardjito, Djwantoro and B. Vijaya Rangan, "On the development of fly ash based geopolymer concrete", ACI Materials Journal, 2004 , pp. 467-472.

3. J.Davidovits, "Geopolymer chemistry and application," $2^{\text {nd }}$ edition, Saint-Quentin Institute Geopolymer; 2008.

(France) 


\section{Strength Attainment of Geopolymer Concrete with GGBS at Ambient Curing}

4. Ramesh Babu Chokkalingam, N Ganesan, A study on the strength development of geopolymer concrete using fly ash International Journal of Engineering \& Technology, 2017, pp 163-167, 6 (4).

5. N Ganesan, Ruby Abraham, S Deepa Raj, Divya Sasi, Stress-strain behavior of confined Geopolymer concrete, Construction and Building Materials 73 , 2014, pp.326-331

6. B Singh, G Ishwarya, M Gupta, Bhattacharyya, Geopolymer concrete: A review of some recent developments, Construction and Building Materials 2015, pp.78-90, 85

7. Indian Standard Code of practice for specification for coarse and fine aggregates from natural sources for concrete, IS: 383 - 1970, Bureau of Indian Standards, New Delhi, India

8. Indian Standard code of practice for specifications for admixtures for concrete IS: 9103-1999, Bureau of Indian Standards, New Delhi, India

9. Indian Standard Code for recommended guidelines for concrete mix design IS: 10262-2009, Bureau of Indian Standards, New Delhi.

\section{AUTHORS PROFILE}

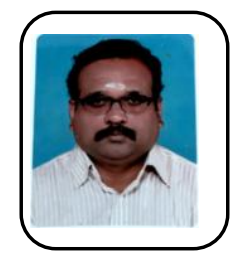

Ganesan Nagalingam completed his UG in Civil Engg. from A.C.Tech, Karaikudi and PG in Structural Engineering from Annamalai University, and pursuing his PhD from Kalasalingam Academy of Research and Education. He has more than twenty five years of experience in teaching and industry. His areas of research include geopolymer concrete,high performance concrete etc.

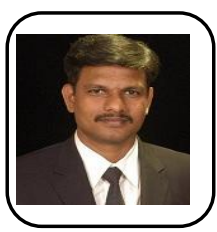

Ramesh Babu Chokkalingam completed his $\mathrm{Ph} . \mathrm{D}$. from IIT Chennai. He has more than ten years of experience in teaching and research. His areas of research includes pervious concrete, geopolymer concrete, and high volume flyash concrete.

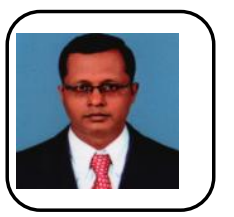

Dr. PL. Meyyappan has completed his graduation and post-graduation from Bharathiyar University and Karunya University respectively. He completed his $\mathrm{PhD}$ from Kalasalingam University. He has 13 years of teaching experience. He has completed 2 sponsored research projects from TNSCST and published more than 25 papers in peer reviewed journals and conferences. He is a life member in ISTE, IEI, IGS, ISET, ISRS. He is serving as Editorial Board Member and Reviewer in various reputed Journals. 